\title{
Magnesite formation by microbial activity: Evidence from a Miocene hypersaline lake
}

\author{
M.E. Sanz-Montero ${ }^{\mathrm{a}, \mathrm{b}}{ }_{*}$, J.P. Rodríguez-Aranda ${ }^{\mathrm{a}}$ \\ ${ }^{a}$ Departamento de petrología y geoquímica, Facultad de Geología (UCM), 28040-Madrid, Spain \\ ${ }^{\mathrm{b}}$ Instituto de Geología Económica (CSIC-UCM), C/Antonio Novais, 2, 28040-Madrid, Spain
}

This paper provides an ancient analogue for biologically mediated magnesite in lacustrine hypersaline environments. Thin beds of massive to crudely laminated magnesitic marls occur interbedded with mudstone and evaporite facies deposited in a saline lake-mudflat sedimentary system during the Lower Miocene in the Madrid Basin, Central Spain. Exposure of this succession in a recently excavated tunnel and in collected cores offered a good opportunity to study magnesite precipitates that have been preserved in unaltered conditions by primary evaporitic minerals. Specifically, magnesite arranged as host matrix between and enclosed by displacive halite and glauberite crystals occurs closely associated with abundant microfossils embedded in sheets of organic matter, interpreted as the remains of extracellular polymeric substances (EPS). Even, many magnesite clots are seen to have resulted from the agglutination of fossilized bacterial bodies forming a biofilm. The close and pervasive association of microorganisms and magnesite is used as evidence that microbes played a fundamental role in the precipitation of this mineral. Additional traces of microorganisms and microbial activity observed in magnesite beds include the isotopic ratios in the carbonates, with the $\delta 13 \mathrm{C}(\mathrm{PDB})$ value averaging $-6.2 \%$, the presence of carbonaceous film-like structures and the association with patchly-distributed pyrite and celestite minerals. On the basis of the combined sedimentological, mineralogical, chemical and morphological signatures of the magnesitic deposits, it is postulated that carbonate crystals precipitated in microbial mats. Magnesite crystals together with celestite, local barite, and/or pyrite have been also observed to replace silicate and sulphate minerals. It is suggested that magnesite precipitation was biochemically coupled with the early dissolution of the associated sedimentary minerals. Microbes may have used the associated minerals as source of energy and/or of essential elements.

Keywords: Magnesite; Halite; Bacterial entrapment; Inclusions; Glauberite; Bioweathering

\section{Introduction}

Magnesite $\left(\mathrm{MgCO}_{3}\right)$ deposits are not volumetrically important in sedimentary sequences, although these carbonates are common in modern coastal and continental evaporitic environments (Müller et al., 1972; Bush, 1973; Pueyo and Inglés, 1987; Last, 1992; Renaut, 1993; Wright, 1999; Pérez et al., 2002; Power et al., 2007; Luzón et al., 2009), as well as in ancient sedimentary sequences of the Earth (Zachmann, 1989; Ordóñez and García del Cura, 1994; Salvany and Ortí, 1994; SanzMontero, 1996; Cañaveras et al., 1998; Melezhik et al., 2001; Sanz-Rubio et al., 2002; Sanz-Montero et al., 2006) and Mars (Russell et al., 1999; Ehlmann et al., 2008). In contemporary saline systems magnesite precipitates are found associated to microbial mats (Walter et al., 1973; Last and De Deckker, 1990; Renaut, 1993; Braithwaite and Zedef, 1996; Coshell et al., 1998;

\footnotetext{
* Corresponding author at: Departamento de petrología y geoquímica, Facultad de Geología (UCM), 28040-Madrid, Spain.

E-mail addresses: mesanz@geo.ucm.es, jupamaes@hotmail.com (M.E.

Sanz-Montero)
}

Edwards et al., 2006; Power et al., 2007; Power et al., 2009) and recent experimental studies are centred on simulate magnesite precipitation using benthic bacteria from natural lakes (Thompson and Ferris, 1990; Power et al., 2007). These experimental investigations have demon-strated the importance of bacteria in promoting the formation of magnesium carbonate minerals. Along similar lines, the precipitation of carbonate minerals by microorganisms has been suggested to be biogeochemically coupled to the weathering of the associated minerals both silicates (Ferris et al., 1994; Power et al., 2009; SanzMontero and Rodríguez-Aranda, 2009; Sanz-Montero et al., 2009a) and sulphates (Sanz-Montero et al., 2006; Ayllón-Quevedo et al., 2007; SanzMontero et al., 2009 a,b). In Earth and in Mars, where large surface deposits of magnesite have been detected, magnesite occurs associated with phyllosilicates and mafic minerals (Sanz-Montero, 1996; Sanz-Rubio et al., 2002; Ehlmann et al., 2008; Power et al., 2009). The biologically-aided carbonatation of the magnesium silicates has been even suggested to be exploited for the purposes of $\mathrm{CO}_{2}$ sequestration (Power et al., 2009).

The authors examine the potential role of microbes in magnesite precipitation in Miocene evaporitic deposits from the continental Madrid Basin. Exposure of a magnesite-bearing succession in a recently excavated tunnel and in collected cores offered a good opportunity to 

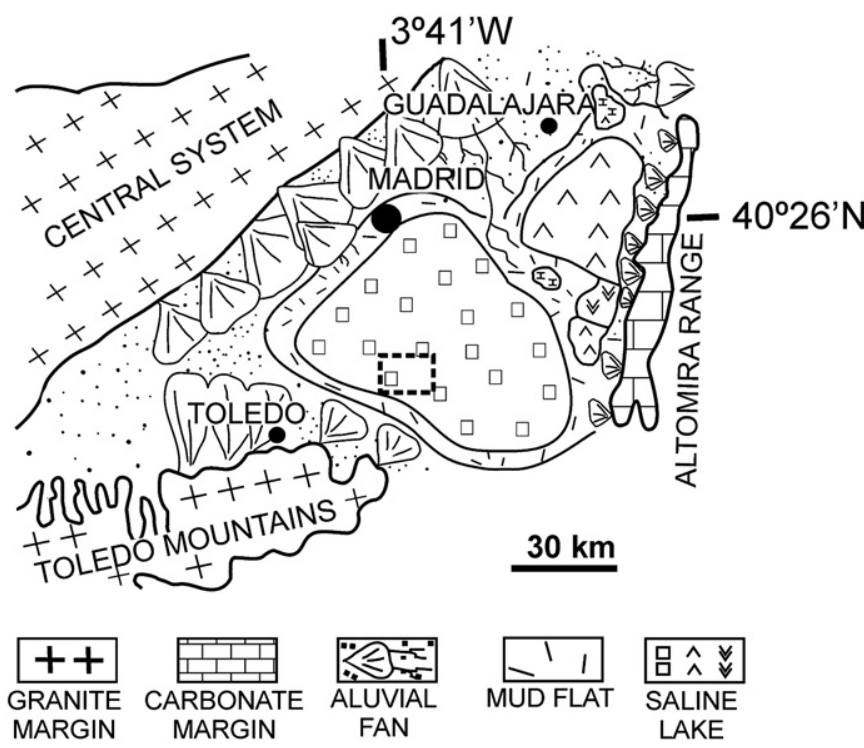

Fig. 1. Paleogeographic sketch of the Madrid Basin with location of the study area (squared) at the time when the upper part of the Lower Miocene Unit was deposited.

examine magnesite precipitates and their relation with the remains of microorganisms that were sealed and preserved in excellent condition by evaporitic minerals.

The results of this study have implications for the role of microorganisms in the nucleation of magnesium carbonates and extend the record of biomediated magnesite to ancient rocks.

\section{Geological context}

The Tertiary Madrid Basin is a continental depression located in central Spain. It is locked between the Central System in the northwest (mainly composed of granites and metamorphic rocks), the Mesozoic Iberian and Altomira Ranges in the east (mainly dolomite and limestone rocks), and the Toledo Mountains in the south (mainly granitic rocks)(Fig. 1). The up to $2000 \mathrm{~m}$ thick Miocene stratigraphical record of the Madrid Basin is divided into three main lithostratigraphical units, each separated by unconformities from their underlying units (Calvo et al.,
1996). In many cases these unconformities are defined by paleokarstic surfaces (Rodríguez-Aranda et al., 2002). The sedimentary succession studied is included in the Lower Unit (Ramblian and early Aragonian). The general sedimentary context for this unit is established as a mudflat-saline lake complex characteristic of a hydrologically-closed basin. In the basin centre, the Lower Unit is composed of flat-lying saline rocks (mostly glauberite, halite, anhydrite and gypsum) that were accumu-lated in perennial hypersaline lakes (Fig. 1). The soluble salts are rarely observed in outcrop since Quaternary weathering processes have transformed anhydrite and glauberite into secondary gypsum and have dissolved the halite precipitates (RodríguezAranda et al., 2009).

These evaporitic facies interfinger with carbonate, marl, and terrigenous deposited in alluvial fans mainly derived from the Toledo Mountains. The alluvial fan deposits extend up to $30 \mathrm{~km}$ northward from the basin margin. The catchment area that acted as source of ions and sediment is mainly located in the anatectic complex of Toledo. This Hercynian complex is composed of migmatitic rocks with abundant Mg-bearing minerals, namely garnet, cordierite and biotite (Barbero, 1995). Scattered basic rocks, containing up to $20 \%$ of $\mathrm{Mg}$, and calco-magnesian marbles also crop out in the complex (Barbero et al., 1990). In addition, the catchment area consists of cretaceous dolomitic rocks (Rodas et al., 1990).

Groundwater recharge in the lake that originated from carbonatic and evaporitic beds (Keuper facies) forming part of the Eastern margin of the basin, is regarded as a complementary source of ions (RodríguezAranda et al., 1991).

\section{Methods}

The samples were taken in the excavation front of a railway tunnel and from six exploratory boreholes drilled with a continuous core by injection of compressed air as well as in outcrops located in the vicinity of Aranjuez (Fig. 1). Boreholes range from 70 to $80 \mathrm{~m}$ in depth. In order to compare the results, sampling was also undertaken in an underground mine for sodiumsulphate extraction, located $30 \mathrm{~km}$ to the east from the tunnel. For this study, mineralogy of the samples was determined by X-ray diffraction (XRD) of powdered samples. Petrographic thin sections were examined by optical and fluorescence microscopy. High-resolution textures were studied with scanning electron microscopy provided with X-ray energy-dispersive spectros-copy, SEM-EDS. Total organic carbon (TOC) was determined as well as stableisotope analysis of carbonates.
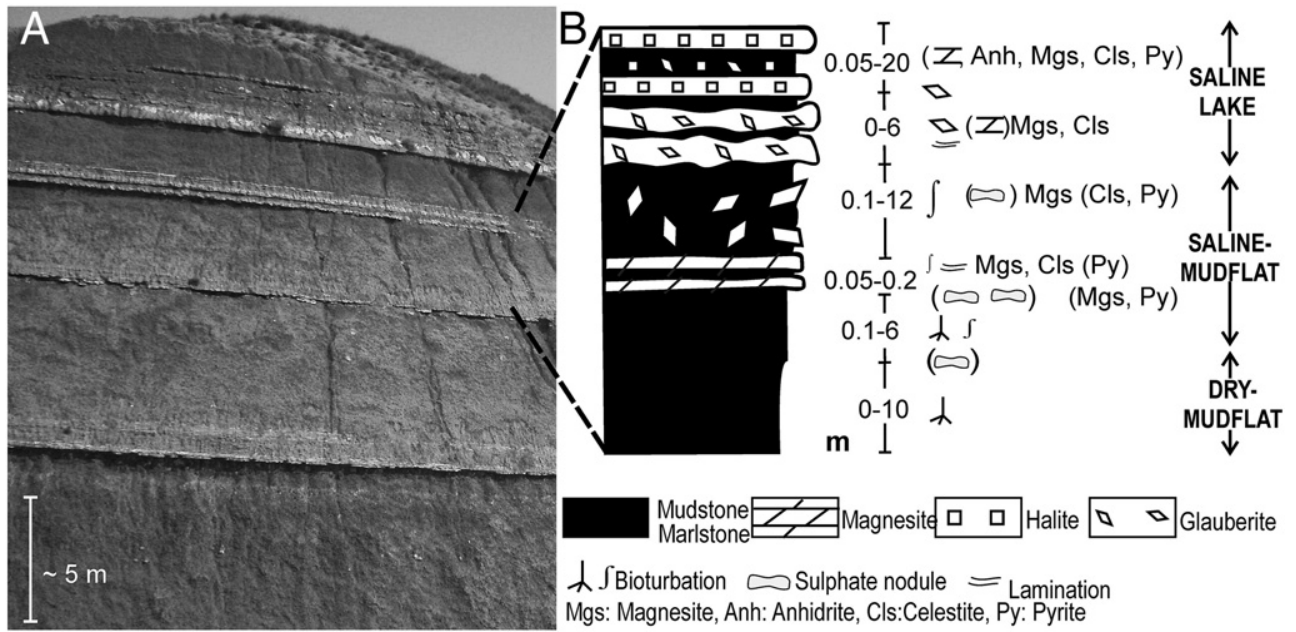

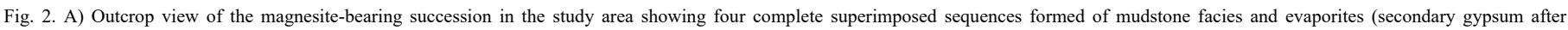
glauberite and anhydrite nodules). Magnesitic marlstones are associated to the evaporite beds. B) Detail of a typical sedimentary facies association showing saline lake facies over mudflat deposits. 

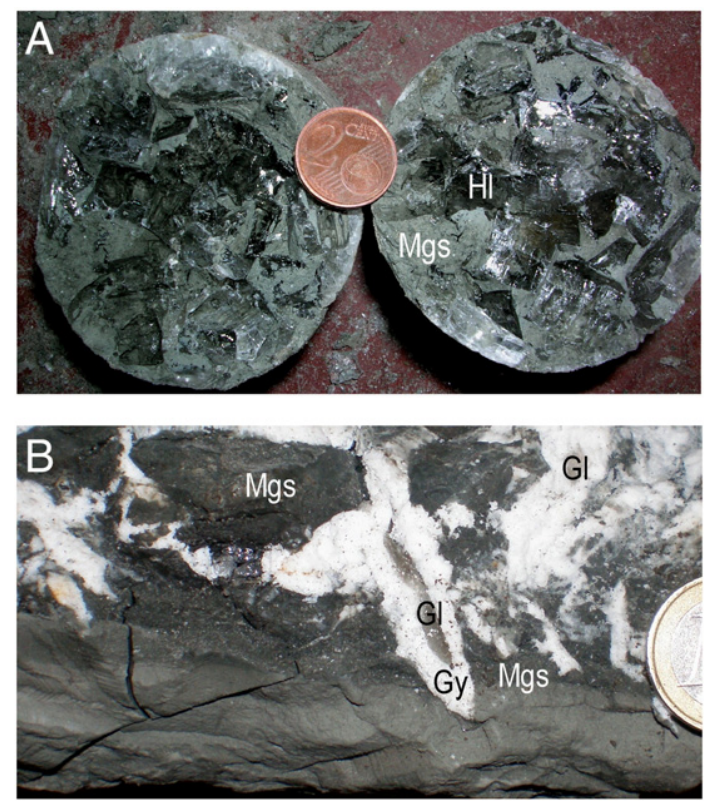

Fig. 3. Hand sample photos. A) Limpid halite crystals $(\mathrm{Hl})$ embedded in grey magnesitic marls (Mgs). B) Hemypiramidal glauberite crystals (Gl) grown intrasedimentary in grey magnesitic marls (Mgs). Notice the transformation of clear glauberite crystals to white secondary gypsum (Gy) proceeding from the edges to the centre.

\section{Facies association and paleoenvironment}

The studied succession is located in the central areas of the Madrid Basin and comprises the upper $100 \mathrm{~m}$ of the Lower Miocene Unit. The magnesite-bearing succession consists of mudstone, marlstone and evaporite facies that were deposited in the saline mudflat and saline lake subenvironments (Sanz-Montero, 1996). The vertical succession of facies reflects a progressive expansion of lake facies over mudflat deposits (Fig. 2). The distribution pattern of magnesite closely coincides with the areal extension of evaporitic lacustrine deposits of the Lower Unit (Fig. 1). Magnesite is the exclusive carbonate phase found in the succession and is present both in the saline mudflat and saline lake subenvironments (Fig. 2).

The saline-mudflat facies association consists of red to green mudstone, greenish-gray magnesitic marlstone and green magnesitic marls-bearing hemypiramidal gypsum and/or glauberite crystals (Fig. 2). The deposits can show bioturbation and locally contain displacive or replacive anhydrite nodules after glauberite. Iron sulphide recognizable as mm-sized, black minerals and celestite are common in the marlstone and sulphate beds. Magnesitic marls are present as massive to vaguely laminated, centimetrethick beds.

The saline lake facies association is made up of green mudstone and grey magnesitic marls interbedded with evaporitic facies that occur as millimetre to centimetre intrasedimentary crystals or forming laterally continuous, centimetre-to decimetre-thick layers separated by partings of mudstones and marlstones (Fig. 3). In recent exposed surfaces, the rocks smell of organic compounds. The major evaporites are halite, glauberite and anhydrite. Minor proportions of thenardite and gypsum are also present. Halite occurs as millimetre to centimetre chevron, hopper, cements and displacive crystals that often incorporate inclusions of the host sediment (Fig. 3A).

Glauberite generally occurs as intrasedimentary crystals, although contorted or nodular beds are also observed. Glauberite consists of euhedral to subhedral hemipyramidal crystals with abundant in-clusions of the host magnesitic marls (Fig. 3B). Some glauberite facies are tightly cemented by cubic halite precipitates.

Anhydrite is present as intrasedimentary, isolated or nodular aggregates of millimetre-sized and lath-shaped crystals.

In outcrops, anhydrite nodules and glauberite are partially or totally transformed into secondary gypsum (Fig. 3B), and iron sulphides into iron oxide and hydroxide. The superficial alteration of sulphate facies to secondary gypsum is commonly accompanied with calcite.
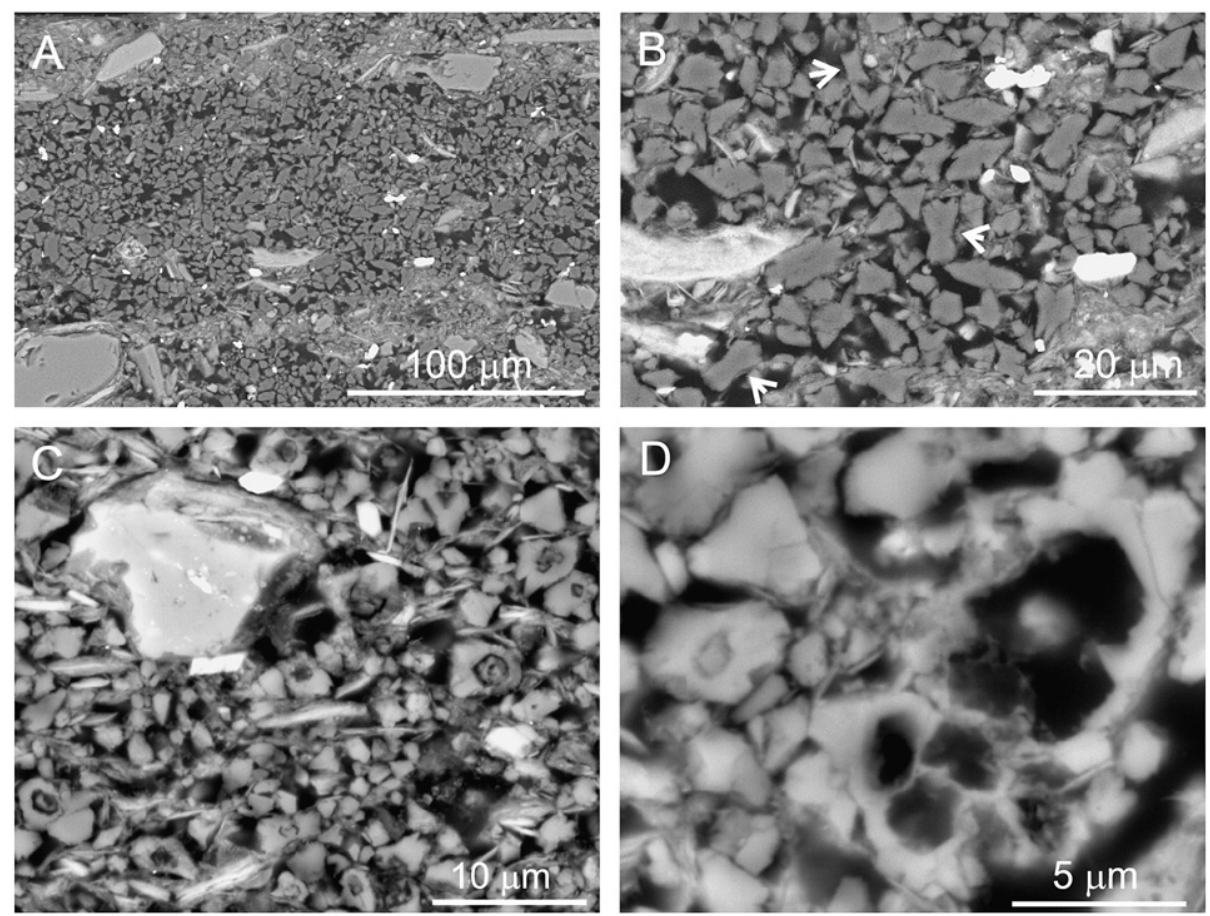

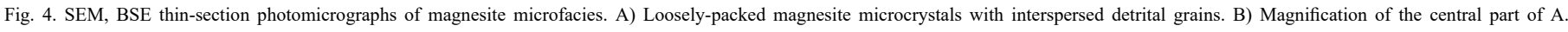

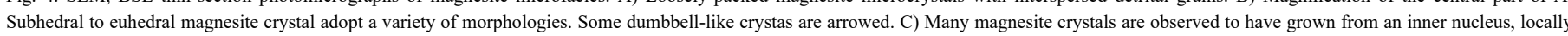
empty. D) Detail of a composite magnesite crystal with a carbonaceous nucleus showing alveolar arrangement. 


\section{Results}

\subsection{Magnesite: petrography and composition}

Marlstone facies are made of a mixture of up to $30 \mathrm{wt} . \%$ of magnesite, clay minerals (illite and subordinately kaolinite), quartz, biotite and feldspars. Thin-section examination of the marlstone beds reveals a massive to vaguely laminated microfacies in which magnesitic laminae interdigitate with laminae enriched in silt-sized detrital grains (Fig. 4A). Intrasedimentary evaporitic crystals and variable quantities of celestite (up to $7 \mathrm{wt} . \%$ ) and pyrite (up to 5 wt.\%) are associated with the carbonate.

Observations under fluorescence microscopy of magnesitic lam-inae show that the carbonate crystals fluoresce whereas the detrital grains and evaporites do not. The fluorescence patterns and the distribution of carbonaceous masses observed by SEM indicate that some organic matter is associated with the crystals and it should be responsible for the fluorescence of the carbonate. In addition, the TOC
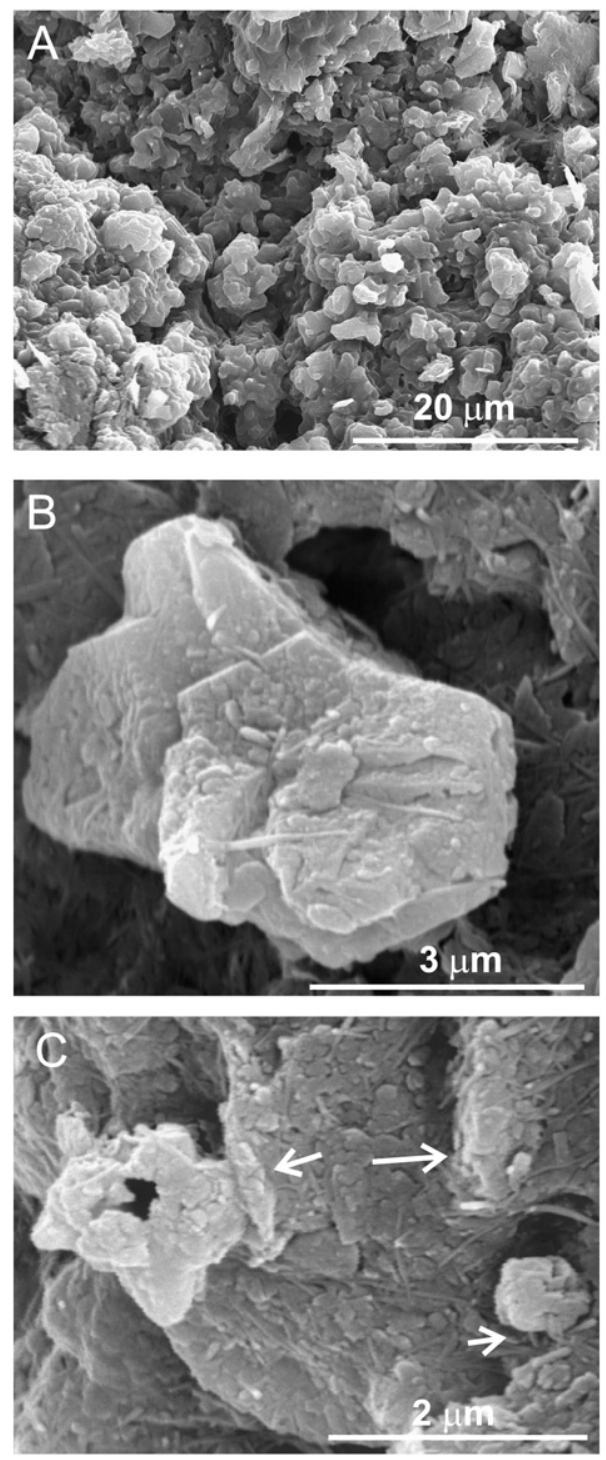

Fig. 5. SEM, SE photographs of freshly broken samples. A) Aggregates of magnesite microcrystals showing no well-defined boundaries or morphologies. B) Asymmetric dumbbellshaped crystal built up by the self-assembly of nanorods, plates, and fibres.

C) Magnesite crystals attached to a carbonaceous substrate (arrowed). The crystal on the left exhibits an inner hole with an array of subcrystals around it. content in the magnesite-bearing samples ranges from 0.1 to $0.9 \mathrm{wt}$. $\%$.

Magnesitic laminae are characterized by loosely packed, unor-iented subhedral to euhedral composite magnesite crystals (Fig. 4A). The up to $12 \mu \mathrm{m}$ in size magnesite crystals adopt rhombohedral to dumbbell-like shapes with variations in between these forms (Fig. 4B). Many crystals are observed to have grown radially from a carbonaceous nucleus that often displays a spheroidal morphology and is around 2 to $5 \mu \mathrm{m}$ in diameter (Fig. 4C). Occasionally, the central structure shows an alveolar arrangement (Fig. 4D).

In more detail, magnesite occurs as amorphous masses (Fig. 5A) or as single crystals (Fig. 5B and C) that are generally connected by organic strands and fibrils so there may be no sharp well-defined boundaries between adjacent crystals. Magnesite crystals result from the aggregation of micron-sized subcrystals displaying a variety of morphologies such as rods, platelets and nanoglobules and include organic fibrils (Fig. 5B and C). Commonly, the subcrystals are seen to arrange around inner hollows and are attached to a carbon-rich substrate (Fig. 5C). The energy-dispersive X-ray spectrometer analyses of magnesite indicate that the mineral contains minor $\mathrm{Ca}(1 \%)$ and traces of Mn (0.1\%) (Fig. 6).

Frequently magnesite is found intergrown with celestite, iron-sulphides and, in minor proportion, with phosphates and barite. Celestite appears as subhedral-euhedral isolated or commonly grouped into intergrown clusters of prismatic crystals up to $10 \mu \mathrm{m}$ in length and $2 \mu \mathrm{m}$ in width (Fig. 7A). Celestite crystals are relatively pure containing $0.8-1.6 \% \mathrm{BaO}$ (Fig. 8A) . The iron sulphides consist of up to $5 \mu \mathrm{m}$-sized subhedral crystals (Fig. 7B) with low contents of iron (Fig. 8B). Occasionally the sulphide crystals show a hole in the centre similar to those recognizable in magnesite precipitates (Fig. 7B).

The isotopic composition of magnesite samples from different facies is characterized by negative values for carbon, $\delta^{13} \mathrm{C}_{\mathrm{PDB}}$ ranging from $-8 \cdot 78 \%$ to $-3 \cdot 22 \%$, averaging $-6 \cdot 2 \%$. In contrast, the $\delta^{18} \mathrm{O}_{\mathrm{PDB}}$ values oscillate within a wider range, $\delta^{18}$ Oranging from $-18 \cdot 90 \%$ o to $+4 \cdot 93 \%$, average $-1 \cdot 12 \%$ o (Fig. 9).

\subsection{Relationships between magnesite and associated minerals}

Detrital silicates, sulphates and halite occur associated with the carbonate in the magnesitic laminae. Silicate grains and sulphate precipitates are corroded by coeval magnesite crystals that form the matrix (Figs. 10 and 11). Whereas, displacively-grown halite, halite cements and the fast-growing faces of glauberite have been observed to incorporate inclusions of the host sediment.

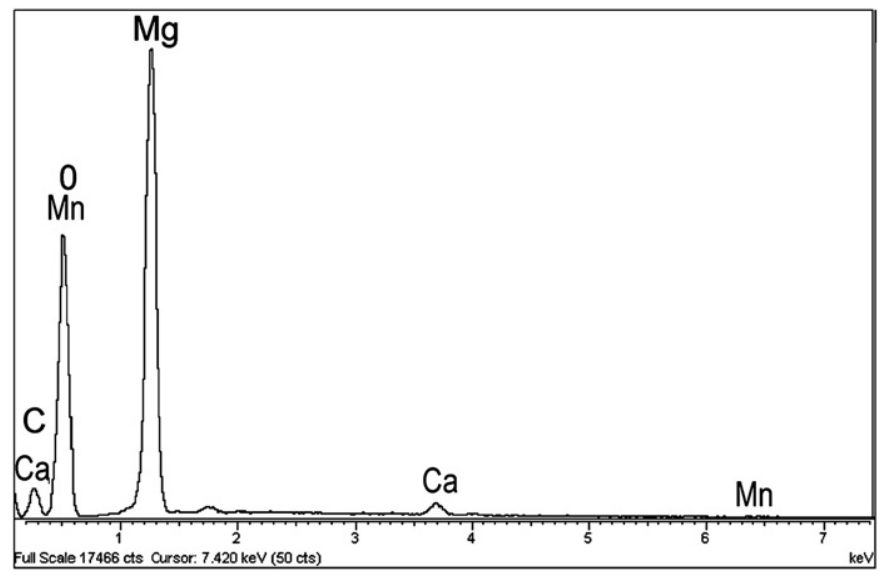

Fig. 6. EDS spectrum of magnesite. 

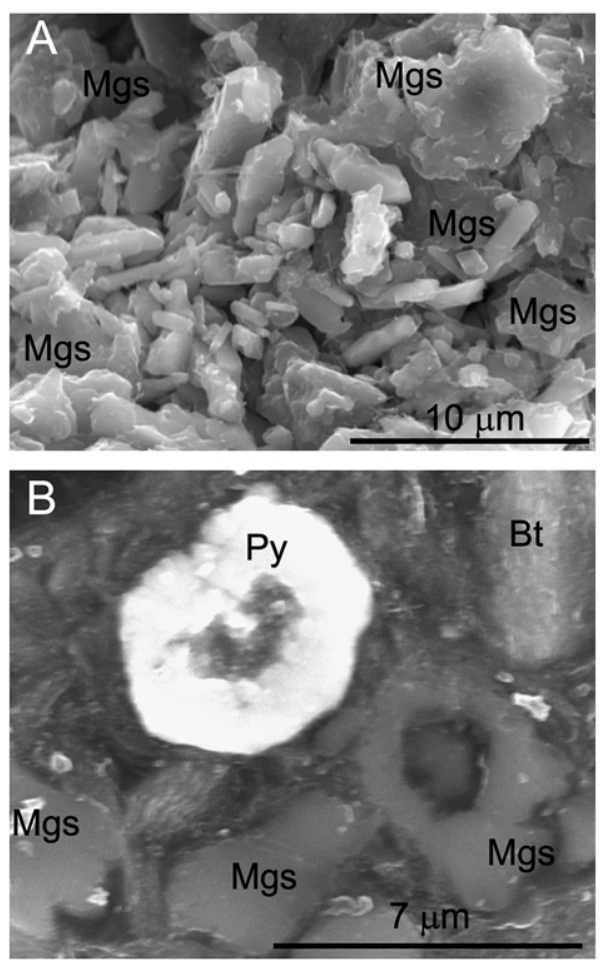

Fig. 7. SEM photographs of minerals associated to magnesite (Mgs). A) SE image of a freshly broken sample showing prismatic celestite intergrown with magnesite crystals.

B) Thin-section BSE image of pyrite (Py) with an inner hole similar to the associated magnesite crystal in the vicinity of a biotite $(\mathrm{Bt})$ grain.
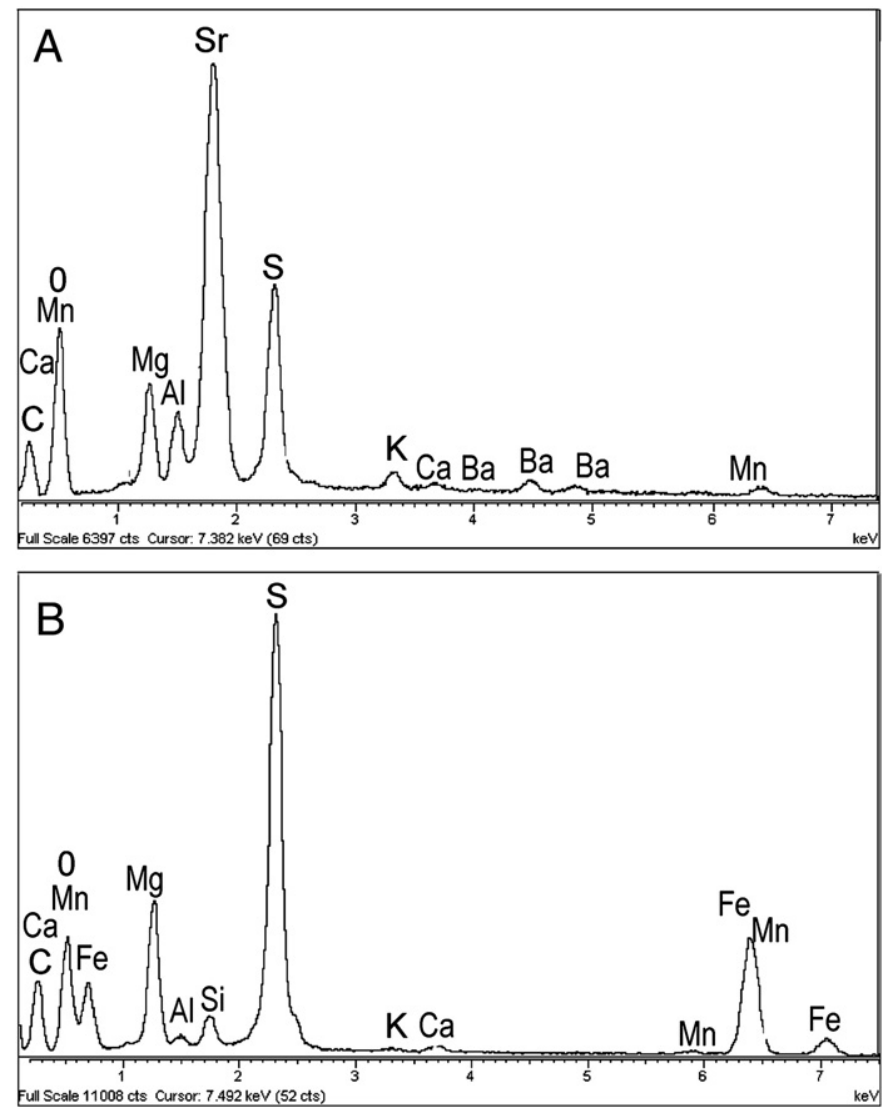

Fig. 8. EDS spectra of celestite (A) and pyrite (B) associated with magnesite.

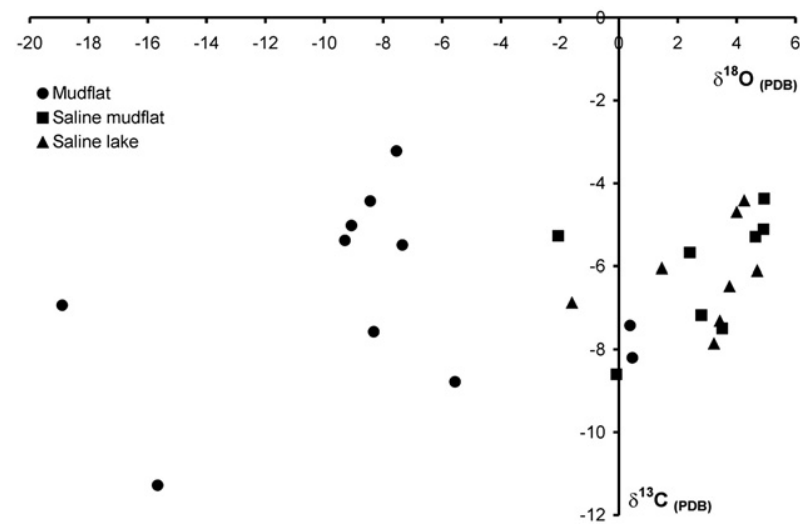

Fig. 9. Plot of $\delta^{13} \mathrm{C}$ versus $\delta^{18} \mathrm{O}$ for the main facies of magnesite. Values are reported in permil relative to PDB standard.

\subsubsection{Silicates}

Although all type of detrital silicates (biotite, feldspars, muscovite and quartz) are seen to be corroded and replaced by magnesite (Fig. 10), biotite is the mineral more transformed into magnesite. Fig. 10A shows a biotite grain partly replaced by microcrystalline magnesite and the replacement by the carbonate led to decreased preservation details in the silicate. Together with magnesite, biotite is commonly replaced by ironsulphide crystals, which commonly follow the cleavage lines of the silicate (Fig. 10B). In the facies containing anhydrite precipitates, clusters of replacive celestite can be further present in the vicinity of the replaced biotite (Figs. 10B and 11). Feldspars are replaced by magnesite and celestite that tend to adopt the outlines of the former minerals (Figs. 10C and 11). In the case of the $\mathrm{K}$-feldspar grains, micrometric-sized barite preferentially arranged along the weakness planes of the silicate are also present (Fig. 10C). Dissolution textures observed in quartz grains deposited in the neighbourhood of magnesite crystals range from surface etching and pitting to extensive disaggregation. In some grains, the etch-pit features seem to be controlled by the presence of mineral inclusions in quartz. Fig. 10D shows regular etch-pits in quartz with relics of a mineral containing $\mathrm{Fe}$ and $\mathrm{Ti}$, probably ilmenite. In general, the quartz grains are less altered than other silicate grains found in the vicinity (Fig. 10D).

\subsubsection{Sulphates}

Magnesite has been seen to corrode and replace intrasedimentary sulphates, anhydrite and glauberite. The corrosion signs in glauberite are mostly concentrated in the slow-growing faces (curved hemi-pyramidal faces). By contrast, the fast-growing faces are not so transformed into carbonate. Anhydrite has undergone a general and intensive alteration resulting in carbonate engulfment and replace-ment, fragment isolation, dissolution, creation and enhancement of structural discontinuities (Fig. 11). The microfabric of replacive magnesite is markedly more compacted than the observed in the embedding matrix. Unlike what was observed in biotite, the transformation of sulphates into magnesite is typically accompanied by celestite microcrystals (Fig. 11).

\subsubsection{Halite and organic structures in magnesite}

Displacively-grown halite within interlayered magnesitic marls and halite cements often incorporate inclusions of the host sediment. Thin-section examination reveals that the inclusions occur in bands or zones that are more abundant along the edges of the crystals in contact with the host sediment (Fig. 12A). The inclusions within the halite precipitates consist of a mixture of magnesitic matrix, primary reticular fluid inclusions trails, curved and straight tubular structures and fluorescent organic matter (Fig. 12B and C). Scanning electron microscopy of the organic structures included in the banded salt 

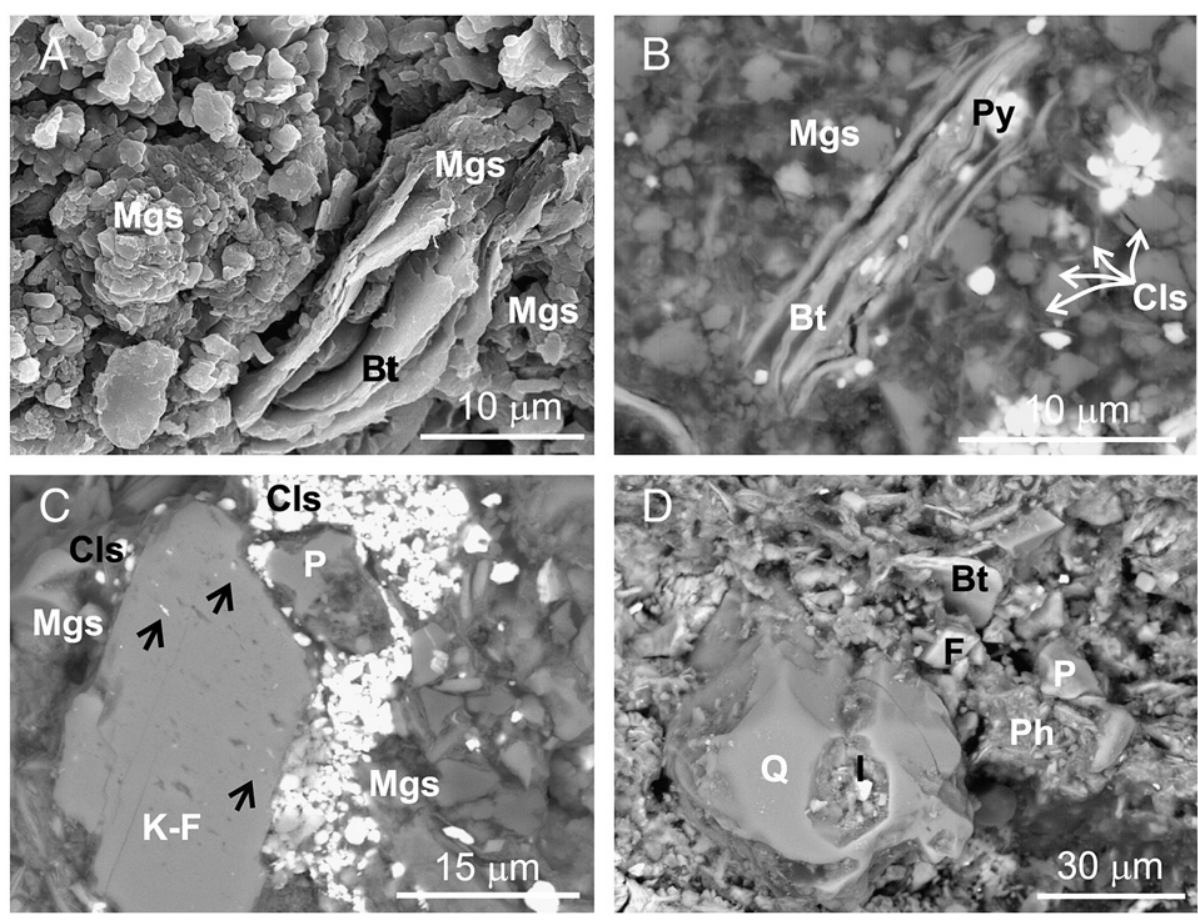

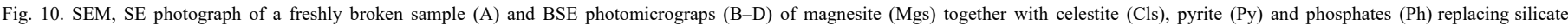
grains: Biotite (Bt), K-feldspar (K-F), Na-plagioclase (P), quartz (Q) and ilmenite (I). A) Biotite grain partially replaced by magnesite with poor preservation details.

B) Biotite grain partially replaced by magnesite and pyrite crystals arranged along the phyllosilicate cleaveages. Celestite clusters are also present in the surroundings. C) Feldspars

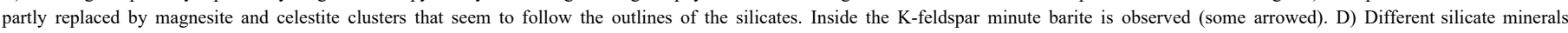
deeply altered in a magnesitic lamina enriched in detrital grains. Pitting in the quartz grain seems to conform to the habit of a Ti and Fe-bearing mineral, possibly ilmenite.

reveals the abundance of tridimensionally-distributed microfossils (Fig. 13). These are rod-shaped and very uniform in size. The fossils consist of solid structures around $3 \mu \mathrm{m}$ in length and $1 \mu \mathrm{m}$ in diameter, which appear embedded in mucus-like films and commonly include long and flexible flagella-like fibres (Fig. 13A and B). Turgid and collapsed microfossils coexist (Fig. 13B), with turgid forms exhibiting a central hollow tube.

In the immediate vicinity, magnesite clots are observed to result from the agglutination of these microfossils and the embedding organic films. Many of these carbonate crystals are knobby and irregular with no sharp well-defined boundaries since they are embedded by organic films (Fig. 13C and D). However, dumbbell or semi-dumbbell morphologies, typically found in the magnesite crystals throughout, are also seen to result from the amalgamation of these organic structures (Fig. 13B and D). Magnesite crystals that have grown in open spaces are observed to comprise euhedral crystalline faces (Fig. 13D).

\section{Discussion}

\subsection{Evidence for microbial precipitation of magnesite}

Sedimentological and petrographical features as well as a combination of biosignatures (morphological and geochemical) recognized in magnesite crystals suggest that microbes played a role in the precipitation of this carbonate. The main evidence that supports the microbial involvement in magnesite precipitation is its association with abundant microfossils embedded in sheets of organic matter, interpreted as the remains of extracellular polymeric substances (EPS). The organic material that formed a biofilm has not been subject of strong diagenetic degradation because it was entrapped and/or encased by primary evaporites, namely halite and glauberite that show no sign of alteration. Thus, evaporites yield valuable information on the prevailing biological conditions during magnesite precipitation.
According to Westall (2008), the main concerns to identify microfossils as microbes in ancient rocks are related to the establishment of the syngenicity and biogenicity of such microfossils. The tridimensional distribution of the microfossils in the banded salt crystals as shown in Fig. 13 allows establishing the syngenicity. This arrangement indicates that microfossils were present in the immediate ambient (matrix) during euhedral growth of the host crystals from a solution. The banding within crystals further suggests relatively rapid growth over periods of days to weeks ( $\mathrm{Li}$ et al., 1996).

The second concern is to establish the biogenicity of the structures observed in the evaporites consisting of rod-shaped microfossils, very uniform in size, arranged as a colony and embedded in a film-like substance of carbonaceous composition interpreted to be EPS. The size and rod shaped structures are identical to those known for modern prokaryotes inhabiting saline environments, for example, in Saline de

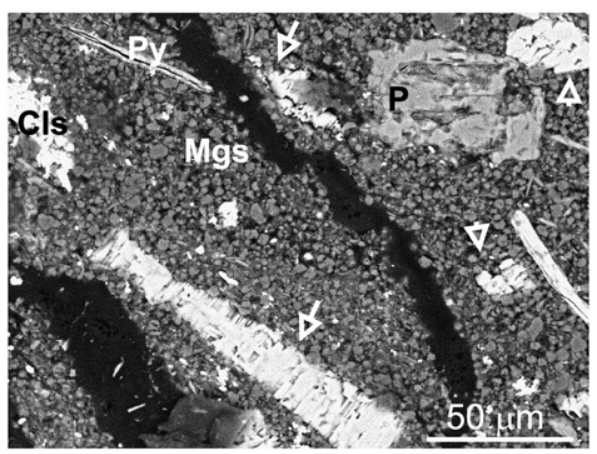

Fig. 11. SEM, BSE photomicrograph of magnesite (Mgs) and celestite (Cls) replacing intrasedimentary anhydrite crystals. Some relics of the sulphate are arrowed. Notice engulfment in the associated plagioclase $(\mathrm{P})$ grain and biotite replacement by pyrite (Py). 

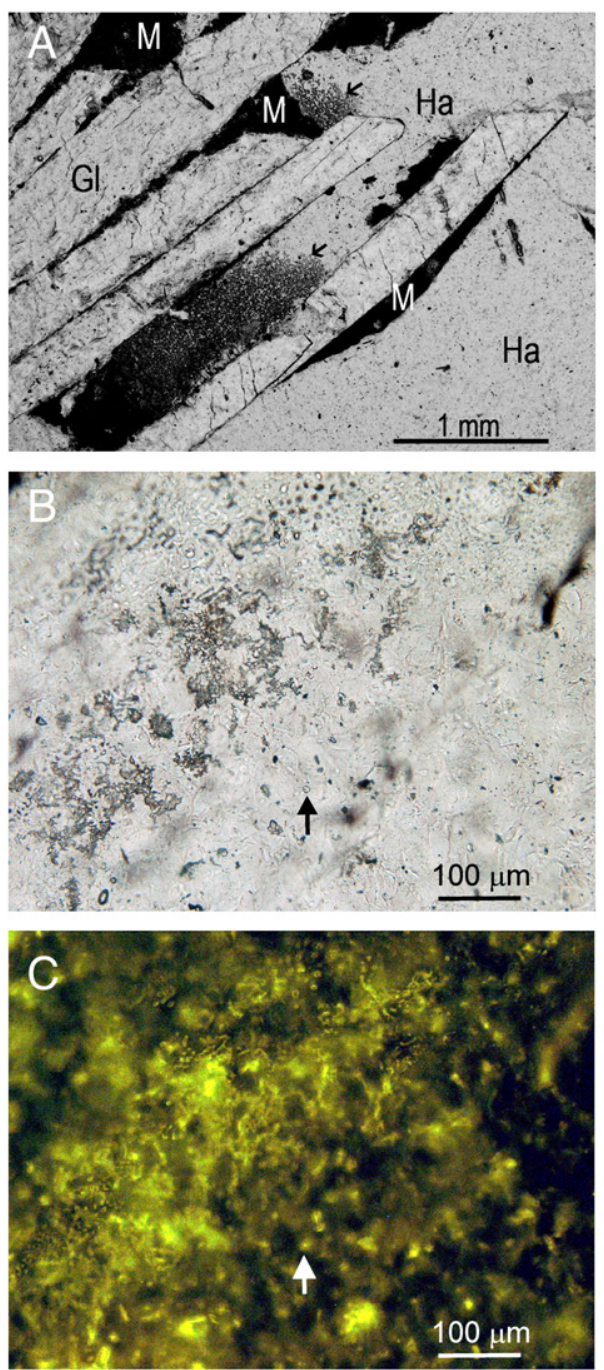

Fig. 12. Photomicrographs of organic-rich magnesitic matrix (M) associated to halite and glauberite precipitates. A) Intrasedimentary glauberite (Gl) cemented by halite (Ha). The matrix (M) is seen to be displaced to the intercrystalline spaces and also incorporated as inclusions mostly by halite (some arrowed). B) Detail of inclusions trapped in halite consisting of a mixture of solid and fluids. A magnesite crystal is arrowed. C) Epifluorescence image of B. Notice that some inclusions are fluorescent organic matter.

Giraud saltern (Caumette et al., 1994), and show colony biofilm formation. All the microfossils are associated with EPS and fibres that demonstrate flexibility. These observations produce evidence that confirms a biogenic origin for the structures agglutinated in magnesite crystals encased in the evaporites. In addition, primary fluid inclusions in magnesite-hosted glauberite present raman spectral signatures attributed to carbonaceous molecules (Sanz-Montero et al., 2011b). Numerous workers have further recorded the entrapment of bacteria within evaporites either within the fluid inclusions or encased in the solid material (e.g. Vreeland et al., 2000).

Spheroidal and dumbbell forms are commonly found in Miocene magnesite crystal (Figs. 4, 5 and 13). The shape and dimension of the spheroidal nucleus of many magnesite crystals strongly resemble those of living coccoid bacteria that are present in modern microbial mat communities and commonly are interpreted as fossilized bacterial forms (Rao et al., 2003; Sanz-Montero et al., 2006; Ayllón-Quevedo et al., 2007; Sanz-Montero et al., 2008). Dumbbell morphologies are also typical for microbially induced carbonates (Chafetz and Buczynski, 1992). Magnesian carbonate crystals precip-itated simultaneously by bacteria can develop several morphologies, including dumbbell (González-Muñoz et al., 2000).
The isotopic signature in the carbonate, with the $\delta^{13} \mathrm{C}_{(\mathrm{PDB})}$ values averaging $-6.2 \%$, provides further geochemical support for a biogenic source for the carbon. The $\delta^{18} \mathrm{O}_{(\mathrm{PDB})}$ values of the magnesite fluctuate significantly (average $-1 \cdot 1 \%$ ) indicating that the lake underwent dilution-evaporation events. The majority of positive values correspond to evaporite-bearing facies deposited in the saline subenvironments and are thus, attributed to evaporitic events. By contrast, the depleted ${ }^{18} \mathrm{O}$ isotopic values are characteristic of the magnesitic marlstone interpreted as mudflat deposits formed during relatively dilute episodes.

The presence of pyrite and celestite interspersed with magnesite also indicates microbial activity. The formation of low-temperature microbial pyrite is linked to sulphate-reducing bacteria (Machel, 2001). Along similar lines, recent findings tie minor celestite occurrences with microbial microenvironments (Schultze-Lam and Beveridge, 1994; Douglas, 2002; Douglas and Yang, 2002; Douglas, 2005; Sanz-Montero et al., 2011a). Parallelly, from the study of ancient sulphate-bearing sequences, Taberner et al. (2002) inter-preted celestite as a byproduct of sulphate-reducing bacteria and Sanz-Montero et al. (2009b) suggested that the transformation of reduced sulphur (produced by sulphate reducers) to oxidized forms (sulphate for celestite) may have been induced by sulphide oxidizing microbes. The typical occurrence of a mineral assemblage that includes corroded gypsum, elemental sulphur, celestite and carbon-ates in the purple-dark layers of microbial mats hosted in modern saline lakes of Central Spain (Sanz-Montero et al., 2011a), would support this interpretation.

The global environment of deposition, saline lake-mud flats, was clearly conducive to microbial growth and activity. The generalized association of magnesite to microorganisms in microbial mats has been highlighted by different authors in modern evaporitic environ-ments (Walter et al., 1973; Last and De Deckker, 1990; Renaut, 1993; Braithwaite and Zedef, 1996; Coshell et al., 1998; Edwards et al., 2006; Power et al., 2007; Power et al., 2009).

On the basis of the combined sedimentological, mineralogical, chemical and morphological characteristics of the magnesite deposits, which include the fossilized remains of individual microorganisms, colonies and biofilms, it is interpreted that the carbonate crystals precipitated in microbial mats. Thus, magnesite layers in the Miocene evaporitic successions can be considered as microbialites. The distribution pattern of magnesite, closely coincident with the areal extension of evaporitic lacustrine deposits (Fig. 1), suggests that microbial mats colonized the whole surface of the shallow lake during periods of low sediment input.

\subsection{Microenvironmental modifications by microbes}

Experimental investigations have demonstrated the importance of bacteria in promoting the formation of the magnesite mineral in microenvironments through alteration of carbonate alkalinity and $\mathrm{Mg}^{2+}$ availability, and acting as nucleation sites (Thompson and Ferris, 1990; Pontoizeau et al., 1997; Power et al., 2007).

The cell walls of bacteria and the extracellular polymeric sub-stances have a strong affinity for $\mathrm{Mg}^{2+}$ cations under saline conditions (Souza-Egipsy et al., 2005). Fixation of magnesium ions to the microbial cells seems to play a crucial role in the precipitation of magnesite through two alternative mechanisms. Wright (1999) concluded that cyanobacterial degradation by sulphate-reducer bacteria releases unhydrated magnesium ion and increase the activity of carbonate. Besides, the transformation of sulphate into sulphide by sulphate-reducer bacteria reduces the kinetic inhibition of $\mathrm{Mg}$-carbonate formation. Whereas, Power et al. (2007) suggested that the presence of adsorbed magnesium ions and possibly their partial dehydratation on cellular surfaces with elevated carbonate activities in the immediate vicinity of the cell wall results in conditions of supersaturation with respect to the magnesium carbonates. After the 

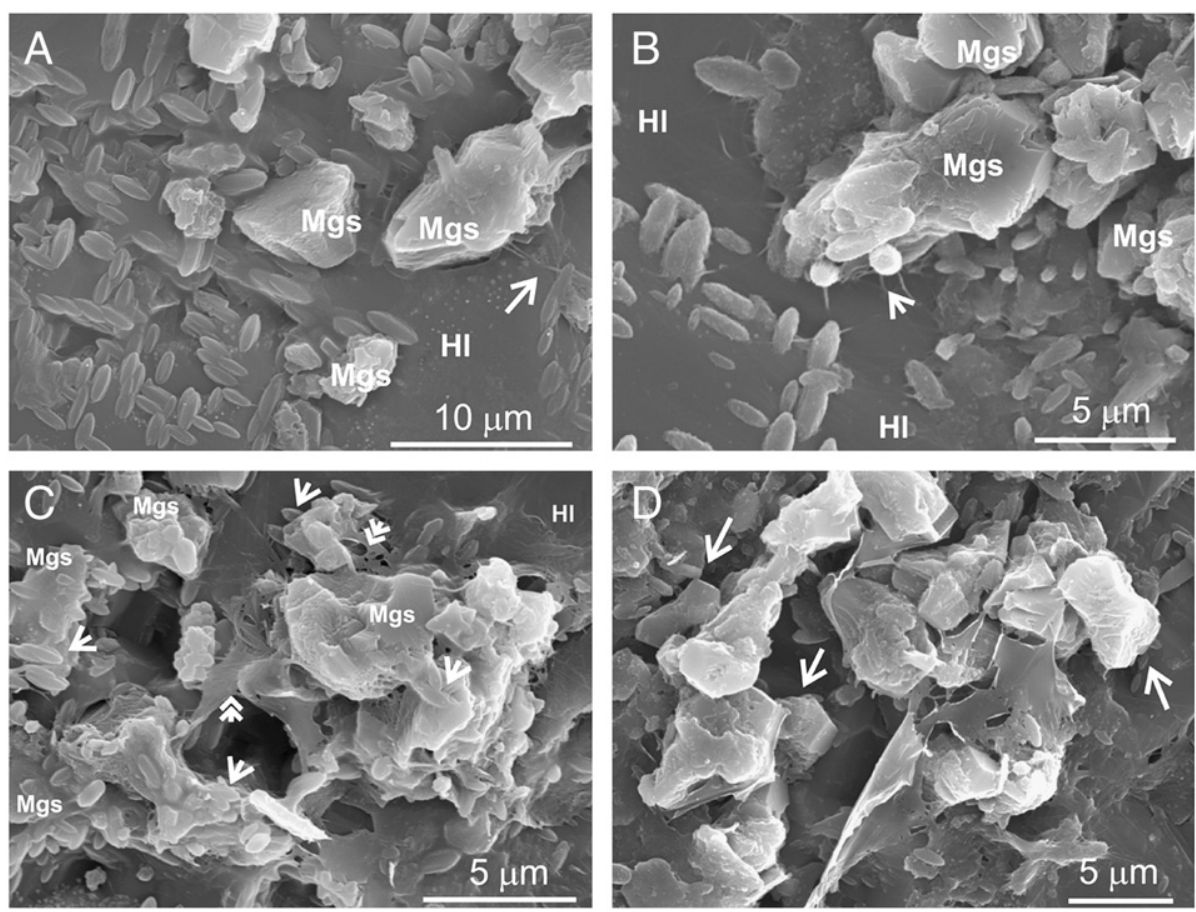

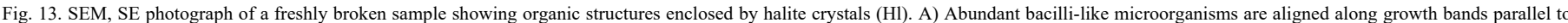

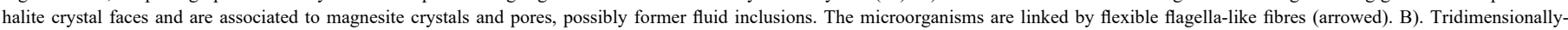

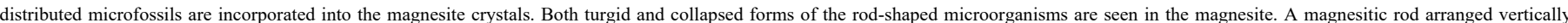

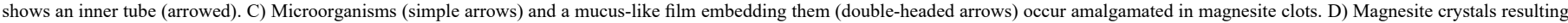
from the amalgamation of the microorganism display irregular to dumbbell or semi-dumbbell morphologies and may show rhombohedral faces (arrows). Notice crystal-linking by organic membranes.

biologically-aided nucleation, subsequent growth of the carbonate crystals can proceed physicochemically.

Parallelly, calcium ions were efficiently removed from the water column by precipitation with sulphate to produce calcium-bearing sulphates (glauberite, anhydrite, gypsum), thereby reducing the availability of calcium and favouring the formation of magnesium carbonate phases.

\subsection{Microbial influence in the coeval carbonatation of sulphates and silicates}

Magnesite crystals, together with pyrite and celestite minerals, are seen to replace the minerals deposited in their vicinity, which are sulphates and silicates (Figs. 10 and 11). The replacement mecha-nisms involve both the dissolution of the original minerals and the concomitant precipitation of the replacive phases. It follows that biological processes involved in the precipitation of the host magnesite crystals also played a role in the replacement of the associated minerals. The basic mechanisms by which all organisms affect mineral dissolution is by producing $\mathrm{CO}_{2}$ that react with minerals generating soluble cations and bicarbonate.

The syngenetic replacement of sulphates by magnesium carbon-ates has been described elsewhere in adjacent Miocene deposits by Sanz Montero et al. (2006). Those authors considered that the formation of magnesium carbonates as a replacement product after gypsum had been related to the metabolic activity of sulfate-reducing bacteria. During bacterial sulphate reduction the release of metabolic $\mathrm{CO}_{2}$ and the formation of bicarbonate ions lead to the precipitation of carbonate and the nearly coincident formation of pyrite (Glenn and Arthur, 1998). Analogously, Pueyo and Inglés (1987) reported that magnesite formation takes place in gypsum facies under reducing environment caused by bacterial decay of organic matter in recent deposits from Los Monegros playa-lake, Spain. Wright (1999) concluded that sulphate-reducing bacteria and other microbes play an essential role in dolomite, hydromagnesite or magnesite precip-itation in distal ephemeral lakes of the Coorong region, Australia. Parallelly, experiments on bacterial activation of the sulphur cycle in anaerobic conditions also led to the precipitation of magnesite (Pontoizeau et al., 1997). Greenish to grey colours that typically show the magnesitic facies also suggest prevailing reducing condi-tions for the carbonate precipitation in the Miocene deposits (Sanz-Montero and Rodríguez-Aranda, 2008).

As the magnesitic deposits described in this work, magnesite commonly occurs associated with phyllosilicates and mafic minerals both in the Earth and Mars (Ehlmann et al., 2008). The release of ions from the alteration of these minerals likely provided most of the $\mathrm{Mg}$ required for the carbonate precipitation in the Madrid Basin. Silicate grains associated to magnesite in Miocene samples are deeply altered and syngenetically replaced by magnesite and, the iron-bearing minerals also by iron-sulphides. The alteration of silicates coupled with carbonate precipitation that appears to have been catalyzed by microbial activities is further a widespread phenomenon in adjacent dolomite-bearing successions, as described by Sanz-Montero and Rodríguez-Aranda (2009) and Sanz Montero et al. (2009a,b).

The preferential etching of Fe-rich minerals, chiefly biotite, recognized in the Miocene samples and concomitant iron-sulphide precipitation would be indicative of the interest of microorganisms for this limiting nutrient, especially in anoxic conditions, where it can be used as an electron acceptor (Lierman et al., 2007; Sanz-Montero et al., 2009a). Silicate minerals can be also sources of essential elements, such as Mn, P, K and trace elements (Ferris et al., 1994). Our observations are in accordance with those of Calvaruso et al. (2006), who demonstrated in an experimental work that bacteria increase biotite weathering and showed that the weathering process was 


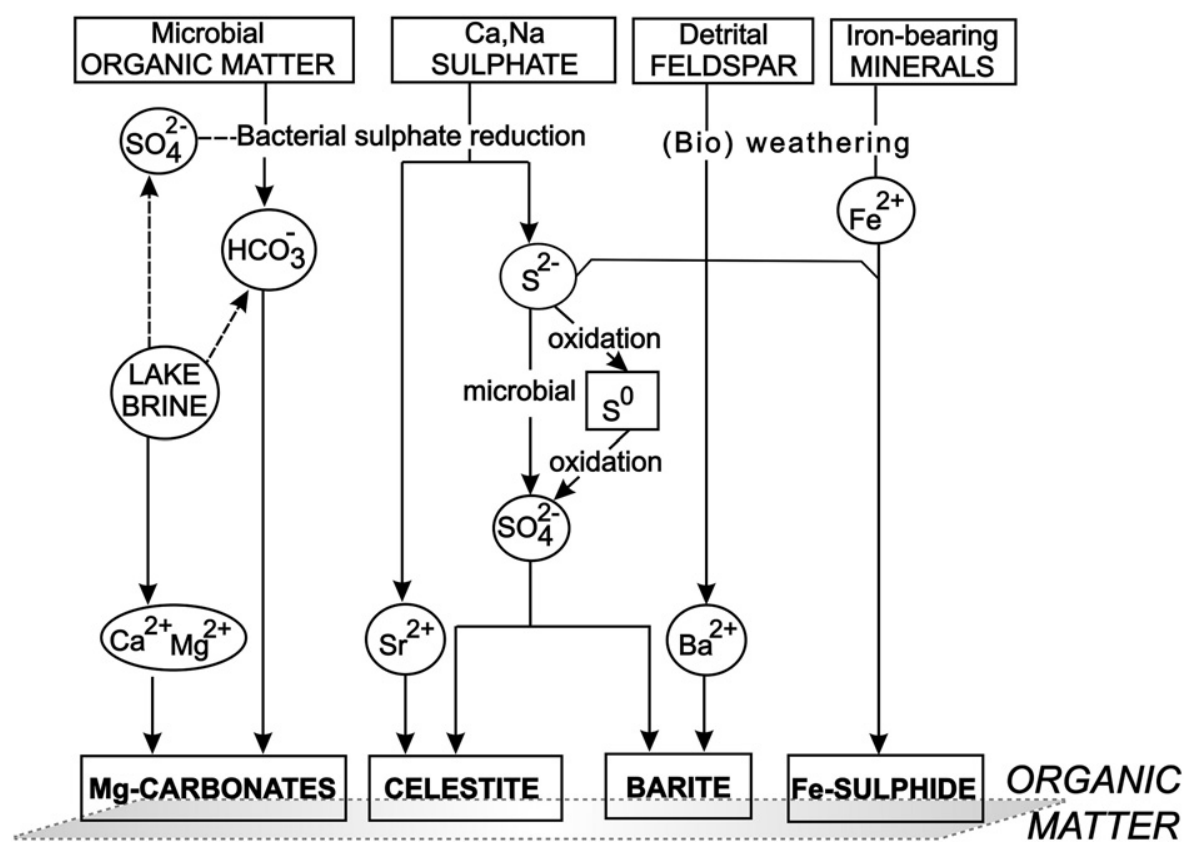

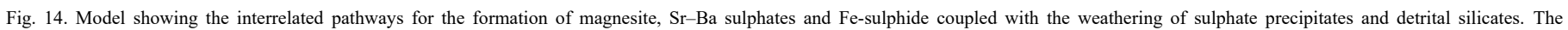

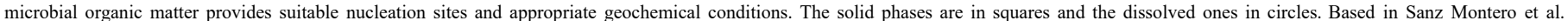
(2009a and b).

coupled with the formation of carbon precipitates associated with sulphur and phosphorus as well as iron precipitates.

\subsection{Model of precipitation}

Results are depicted in the model shown in Fig. 14 that is also based on previous works on adjacent successions (Sanz Montero et al.(2006, 2009a and b). Our observations suggest that the formation of magnesite, celestite (minor barite) and iron-sulphides took place in biofilms and microbial mats that provided suitable nucleation sites and appropriated geochemical conditions. The precipitation of this mineral suite is thought to be coupled through interrelated pathways with the dissolution of sulphates (anhydrite and glauberite) and silicate detrital grains and, thus, entails complex interactions between different microorganisms. Soluble $\mathrm{Sr}$ might have released from anhydrite through the activity of sulphate-reducing bacteria, whereas biologically weathered biotite and K-feldspar acted as a major source of iron and barium, respectively. Sulphide for pyrite and sulphur was provided by sulphate reduction of sulphates and then reprecipitated as celestite and barite possibly by bacterial oxidation of sulphide to sulphate. The processes of bacterial sulphate reduction and microbial degradation may have favoured the concomitant precipitation of the carbonates through the formation of bicarbonate ions and the supply of unhydrated $\mathrm{Mg}$. The cell walls of bacteria and the extracellular polymeric substances may have acted as nucleation sites, which further may have aided the mineral nucleation.

\section{Conclusions}

Evaporites favour the excellent preservation of the sedimentary precipitates and associated microorganisms, which offers the researchers the opportunity to analyse mineral-microbe interactions in fossil rock samples. This has broad applications given the abundance of evaporites in the rock record.

Magnesite is the only carbonate mineral associated to the evaporites precipitated in hypersaline lakes of the Madrid Basin. Fossilized microorganisms showing colony-biofilm formation are aggregated in magnesite crystals. This provides evidence of their implication in the carbonate nucleation and indicates that the precipitation took place in microbial mats and biofilms that provided suitable nucleation sites and appropriated geochemical conditions.

Carbonate precipitation appears to be biogeochemically coupled with the weathering of the associated minerals in the sediment through interactions between microorganisms. The precipitation of magnesite is thus favoured by the dissolution of the associated silicate and sulphate minerals.

\section{Acknowledgments}

We are grateful to Ontigola UTE Company and ADIF and particularly to P. Goicoechea for assistance with the sampling. The study was supported by Projects PR34/07/15900 (Santander-Complutense) and UCM-BSCH GR58/08 (grupo 910404). Thanks are due to two anonymous reviewers for their valuable comments and suggestions.

\section{References}

Ayllón-Quevedo, F., Souza-Egipsi, V., Sanz-Montero, M.E., Rodríguez-Aranda, J.P., 2007. Fluid inclusion analysis of twinned selenite gypsum beds from the Miocene of the Madrid Basin (Spain). Implication on Dolomite Bioformation. Sedimentary Geology 201, 212-230.

Barbero, L., 1995. Granulite-facies metamorphism in the Anatectic Complex of Toledo, Spain: late Hercynian tectonic evolution by crustal extension. Journal of the Geological Society 152, 365-382.

Barbero, L., Villaseca, C., Andonaegui, P., 1990. On the origin of the gabbro-tonalitemonzogranite association from Toledo area (Hercynian Iberian Belt). Schweizerische Mineralogische und Petrografische Mitterlung 70, 207-219.

Braithwaite, C.J.R., Zedef, V., 1996. Hydromagnesite stromatolites and sediments in an alkaline lake, Salda Gölü, Turkey. Journal of Sedimentary Research 66, 991-1002. Bush,

P., 1973. Some aspects of the diagenetic history of the Sabkha in Abu Dhabi, Persian Gulf. In: Purser, B.H. (Ed.), The Persian Gulf. Springer-Verlag, New York, pp. 395-407.

Calvaruso, C., Turpault, M.P., Frey-Klett, P., 2006. Root-associated bacteria contribute to mineral weathering and to mineral nutrition in trees: a budgeting analysis. Applied and Environmental Microbiology 72, 1258-1266.

Calvo, J.P., Alonso-Zarza, A.M., García del Cura, M.A., Ordóñez, S., Rodríguez-Aranda, J.P., Sanz-Montero, M.E., 1996. Sedimentary evolution of lake systems through Miocene, Madrid Basin. Paleoclimatic and paleohydrological constraints. In: Friend, P., Dabrio, C.(Eds.), Tertiary Basins of Spain. Cambridge University Press, Cambridge, pp. 264-269.

Cañaveras, J.C., Sánchez-Moral, S., Sanz-Rubio, E., Hoyos, M., 1998. Meteoric calcitization of magnesite in Miocene lacustrine deposits (Calatayud Basin, NE Spain). Sedimentary Geology 119, 183-194. 
Caumette, P., Matheron, R., Raymond, N., Relexans, C., 1994. Microbial mats in the hypersaline ponds of Mediterranean salterns (Salins-de-Giraud, France). FEMS Microbiology Ecology 13, 273-283.

Chafetz, H.S., Buczynski, C., 1992. Bacterially induced lithification of microbial mats. Palaios 7, 277-293.

Coshell, L., Rosen, M.R., McNamara, K.J., 1998. Hydromagnesite replacement of biomineralized aragonite in a new location of Holocene stromatolites, Lake Walyungup, Western Australia. Sedimentology 45, 1005-1018.

Douglas, S., 2002. ESEM-EDS and XRD study of micromineralogical layering in a microbial mat from a hypersaline pond on Lee Stocking Island, Bahamas: formation of celestite in microbial exopolymers. Annual meeting of the Geological Society of America. Abstracts.

Douglas, S., 2005. Mineralogical footprints of microbial life. American Journal of Science 305, 503-525.

Douglas, S., Yang, H., 2002. Mineral biosignatures in evaporites: presence of rosickyite in an endoevaporitic microbial community from Death Valley, California. Geology 30, 1075-1078

Edwards, H.G.M., Mohsin, M.A., Sadooni, F.N., Hassan, N.F., Munshi, T., 2006. Life in the sabkha: Raman spectroscopy of halotrophic extremophiles of relevance to planetary exploration. Analytical and Bioanalytical Chemistry 385, 46-56.

Ehlmann, B.L., Mustard, J.F., Murchie, S.L., Poulet, F., Bishop, J.L., Brown, A.J., Calvin, W.M., Clark, R.N., Des Marais, D.J., Milliken, R.E., Roach, L.H., Roush, T.L., Swayze, G.A., Wray, J.J., 2008. Orbital identification of carbonate-bearing rocks on Mars. Science $322,1828$.

Ferris, F.G., Wiese, R.G., Fyfe, W.S., 1994. Precipitation of carbonate minerals by microorganisms: implications for silicate weathering and the global carbon dioxide budget. Geomicrobiology Journal 12, 1-13.

Glenn, C.R., Arthur, M.A., 1998. Petrology and major element geochemistry of Peru margin phosphorites and associated diagenetic minerals: authigenesis in modern organicrich sediments. Marine Geology 80, 231-267.

González-Muñoz, M.T., Ben Chekroun, K., Ben Aboud, A., Arias, J.M., Rodríguez-Gallego, 2000. Bacterially induced $\mathrm{Mg}$-calcite formation: role of $\mathrm{Mg} 2+$ in development of crystal morphology. Journal of Sedimentary Petrology 70, 559-569.

Last, W.M., 1992. Petrology of modern carbonate hardgrounds from East Basin Lake, a saline maar lake, Southern Australia. Sedimentary Geology 81, 215-229.

Last, W.M., De Deckker, P., 1990. Modern and Holocene carbonate sedimentology of two saline volcanic maar lakes, Southern Australia. Sedimentology 37, 967-981.

Li, J.A., Lowenstein, T.K.A., Brown, C.B.A., Ku, T.L.B., Luo, S.B., 1996. A 100 ka record of water tables and paleoclimates from salt cores, Death Valley, California. Palaeogeography, Palaeoclimatology, Palaeoecology 123, 179-203.

Lierman, L.J., Hausrath, E.M., Anbar, A.D., Brantley, S.L., 2007. Assimilatory and dissimilatory processes of microorganisms affecting metals in the environment. Journal of Analytical Atomic Spectrometry 22, 867-877.

Luzón, A., Mayayo, M.J., Pérez, A., 2009. Stable isotope characterisation of co-existing carbonates from the Holocene Gallocanta lake (NE Spain): palaeolimnological implications. International Journal of Earth Sciences 98, 1129-1150.

Machel, H.G., 2001. Bacterial and thermochemical sulphate reduction in diagenetic setting: old and new insights. Sedimentary Geology 140, 143-175.

Melezhik, V.A., Fallick, A.E., Medvedev, P.V., Makarikhin, V.V., 2001. Palaeoproterozoic magnesite: lithological and isotopic evidence for playa/sabkha environments. Sedimentology 48, 379-397.

Müller, G., Irion, G., Forstner, U., 1972. Formation and diagenesis of inorganic $\mathrm{Ca}-\mathrm{Mg}$ carbonates in lacustrine environment. Naturwissenschaften 59, 158-164.

Ordóñez, S., García del Cura, M.A., 1994. Deposition and diagenesis of sodium-calcium sulfate salts in the Tertiary saline lakes of the Madrid Basin, Spain. Sedimentology and geochemistry of modern and ancient saline lakes: In: Renaut, R.W., Last, W.M.(Eds.), SEPM Spec. Publ., 50, pp. 229-238.

Pérez, A., Luzón, A., Roc, A.C., Soria, A.R., Mayayo, M.J., Sánchez, J.A., 2002. Sedimentary facies distribution and genesis of a recent carbonate-rich saline lake: Gallocanta Lake, Iberian Chain, NE Spain. Sedimentary Geology 148, 185-202.

Pontoizeau, P., Castanier, S., Perthuisot, J.P., 1997. First bacterial production of magnesite $\left(\mathrm{MgCO}_{3}\right)$ in anaerobic strictly controlled conditions. Microbial media-tion in carbonate diagenesis: ASF Association des Sedimentologistes Francais, Paris, 26, pp. 57-58.

Power, I.A., Wilson, S.A., Thom, J.M., Dipple, G.M., Southam, G., 2007. Biologically induced mineralization of dypingite by cyanobacteria from alkaline wetland near Atlin, British Columbia, Canada. Geochemical Transactions 8, 13.

Power, I.A., Wilson, S.A., Thom, J.M., Dipple, G.M., Gabites, J.E., Southam, G., 2009. The hydromagnesite playas of Atlin, British Columbia, Canada: a biogeochemical model for $\mathrm{CO}_{2}$ sequestration. Chemical Geology 260, 286-300.

Pueyo, J.J., Inglés, M., 1987. Magnesite formation in recent playa lakes, Los Monegros, Spain. Diagenesis of Sedimentary Sequences: In: Marshall, J.D. (Ed.), Geol. Soc. Spec. Publ., 36, pp. 119-122.

Rao, V.P., Kessarkar, P.M., Krumbein, W.E., Karjewski, K.P., Scheider, R.J., 2003. Microbial dolomite crusts from the carbonate platform off Western India. Sedimentology 50, 819-830.

Renaut, R.W., 1993. Morphology, distribution and preservation potential of the microbial mats in the Hydromagnesite-magnesite playas of the Cariboo Plateau, British Columbia, Canada. Hydrobiology 267, 75-98.
Rodas, M., Garzón, M.G., Luque, F.J., Mas, R., 1990. Correlation between the Paleogene detritic facies in the margins of Tajo and Duero Basins (Central Spain): Mineralogical, sedimentological and geomorphological characteristics. Proceedings 9th Int Clay Conference, Strasbourg: Sci. Géol. Mém., 88, pp. 43-52.

Rodríguez-Aranda, J.P., Calvo, J.P., Ordóñez, S., 1991. Transición de abanicos aluviales a evaporitas en el borde oriental de la Cuenca de Madrid (Sector Barajas de MeloIllana). Revista Sociedad Geologica de España 4, 33-50.

Rodríguez-Aranda, J.P., Calvo, J.P., Sanz-Montero, M.E., 2002. Lower Miocene gypsum palaeokarst in the Madrid Basin (central Spain): dissolution, diagenesis, morpho-logical relics and karst end-products. Sedimentology 49, 1385-1400.

Rodríguez-Aranda, J.P., Sanz-Montero, M.E., Goicoechea, P., Garrayo, A., 2009. Secondary gypsum after soluble salts: hydrogeological model for the Madrid Basin (Spain). In: Pascucci, V., Andreucci, S. (Eds.), Abstract book. 27 th IAS Meeting of Sedimentology, Alghero, p. 330.

Russell, M.J., Ingham, J.K., Zedef, V., Maktav, D., Sunar, F., Hall, A.J., Fallick, A.E., 1999. Search for signs of ancient life on Mars; expectations from hydromagnesite microbialites, Salda Lake, Turkey. Journal of the Geological Society of London 156, 869-888. Salvany,

J.M., Ortí, F., 1994. Miocene glauberite deposits of Alcanadre, Ebro Basin, Spain: Sedimentary and diagenetic processes. Sedimentology and geochemistry of modern and ancient saline lakes: In: Renaut, R.W., Last, W.M. (Eds.), SEPM Spec. Publ., 50, pp. 204-215.

Sanz-Montero, M.E., 1996. Sedimentología de las formaciones neogénas del Sur de la Cuenca de Madrid. CEDEX. Monografías 52245 pp.

Sanz-Montero, M.E., García del Cura, M.A., Calvo, J.P., Rodríguez-Aranda, J.P., 2011 a. Formation of celestite in microbial mats from saline-lakes of Central Spain (Toledo). Mineralogical biosignatures in sulfate evaporite environments. Abstracts book. IAS Meeting of Sedimentology, Zaragoza, p. 395.

Sanz-Montero, M.E., González-Acebrón, L., Rodríguez-Aranda, J.P., Marshall, C.P., 2011 b. Raman Spectra on Fluid Inclusions in Glauberite from Miocene Saline Lakes of the Madrid Basin: Evidence for Microbial Activity. CORALs II meeting. Abstracts book, p. 72

Sanz-Montero, M.E., Rodríguez-Aranda, J.P., 2008. Participación microbiana en la formación de magnesita dentro de un ambiente lacustre evaporítico: Mioceno de la Cuenca de Madrid. Macla 9, 231-232.

Sanz-Montero, M.E., Rodríguez-Aranda, J.P., 2009. Silicate bioweathering and biomineralization in lacustrine microbialites: ancient analogues from the Miocene Duero Basin, Spain. Geological Magazine 146, 527-539.

Sanz Montero, M.E., Rodríguez Aranda, J.P., Calvo, J.P., 2006. Mediation of endoevaporitic microbial communities in early replacement of gypsum by dolomite. A case study from Miocene lake deposits of the Madrid Basin, Spain. Journal of Sedimentary Research 76, 1257-1266.

Sanz Montero, M.E., Rodríguez Aranda, J.P., García Del Cura, M.A., 2008. Dolomite-silica stromatolites in Miocene lacustrine deposits from the Duero Basin, Spain: The role of organotemplates in the precipitation of dolomite. Sedimentology 55, 729-750. Sanz-

Montero, M.E., Rodríguez-Aranda, J.P., Pérez-Soba, C., 2009a. Microbial weathering of Fe-rich phyllosilicates and formation of pyrite in the dolomite precipitating environment of a Miocene lacustrine system. European Journal of Mineralogy 21, 163-175.

Sanz-Montero, M.E., Rodríguez-Aranda, J.P., García del Cura, M.A., 2009b. Bioinduced precipitation of barite and celestite in dolomite microbialites: Examples from Miocene lacustrine sequences in the Madrid and Duero Basins, Spain. Sedimentary Geology 222, lacustrine

Sanz-Rubio, E., Pozo, M., Rodríguez-Aranda, J.P., Calvo, J.P., 2002. Petrología y Geoquímica isotópica de los depósitos de magnesita de la Cuenca de Calatayud (provincia de Zaragoza). Interpretación paleoambiental. Revista Sociedad Geolo-gica de España $15,113-127$.

Schultze-Lam, S., Beveridge, T.J., 1994. Nucleation of celestite and strontianite on a cyanobacterial S-layer. Applied and Environmental Microbiology 60, 447-453. Souza-Egipsy, V., Wierzchos, J., Ascaso, C., Nealson, K.H., 2005. Mg-silica precipitation in fossilization mechanisms of sand tufa endolithic microbial community, Mono Lake (California). Chemical Geology 217, 77-87.

Taberner, C., Marshall, J.D., Hendry, J.P., Pierre, C., Thirlwall, M.F., 2002. Celestite formation, bacterial sulphate reduction and carbonate cementation of Eocene reefs and basinal sediments (Igualada, NE Spain). Sedimentology 49, 171-190.

Thompson, J.B., Ferris, F.G., 1990. Cyanobacterial precipitation of gypsum, calcite and magnesite from natural alkaline lake water. Geology 18, 995-998

Vreeland, R.H., Rosenzweig, W.D., Powers, D.W., 2000. Isolation of a 250 million-yearold halotolerant bacterium from a primary salt crystal. Nature 407, 897-900. Walter, M.R., Golubic, S., Preiss, W.V., 1973. Recent stromatolites from hydromagnesite and aragonite depositing lakes near Coorong Lagoon, South Australia. Journal of Sedimentary Petrology 43,10021-11030.

Westall, F., 2008. Morphological biosignatures in Early Terrestrial and extraterrestrial material. Space Science Review 135, 95-114.

Wright, V., 1999. The role of sulphate-reducing bacteria and cyanobacteria in dolomite formation in distal ephemeral lakes of the Coorong region, South Australia Sedimentary Geology 126, 147-157.

Zachmann, D.W., 1989. Mg-carbonate deposits in freshwater environment. Magnesite, Geology, Mineralogy, Geochemistry, Formation of Mg-Carbonates: In: Möller, P.(Ed.), Monogr. Ser. Miner. Deposits, 28, pp. 61-94. 